\title{
Pengaruh Pelayanan Terpadu Satu Pintu Terhadap Citra Kantor Wilayah Kementerian Agama Provinsi Jambi
}

\author{
Tuti Alfiani, Ansusa Putra, Agus Selamet Nugroho \\ UIN Sulthan Thaha Saifuddin Jambi \\ Email: agusslametnugroho@uinjambi.ac.id
}

\begin{abstract}
Abstrak: Citra instansi merupakan sebuah hal yang penting karena dapat membuat sebuah instansi menjadi baik atau bahkan menjadi buruk. Pelayanan Terpadu Satu Pintu (PTSP) Kantor Wilayah Kementerian Agama Provinsi Jambi menjadi salah satu penggerak untuk mendapatkan citra baik di masyarakat. Penelitian ini bertujuan untuk mengetahui pengaruh pelayanan prima di PTSP terhadap citra Kanwil Kemenag Provinsi Jambi. Penelitian ini merupakan penelitian kualitatif dengan pengumpulan data melalui wawancara denga subjek penelitian yaitu penanggung jawab PTSP, petugas PTSP, pegawai Kanwil Kemenag Provinsi Jambi. Hasil penelitian menunjukkan bahwa: dalam meningkatkan citra Kanwil Kemenag Provinsi Jambi, PTSP memberikan pelayanan yang prima seperti memberikan rasa puas terhadap pelanggan, memberikan pelayanan yang ramah, cepat dan mudah; Bertanggung Jawab; Mekanisme dan prosedur pelayanan yang baik; kejelasan dalam biaya administrasi; Faktor yang mendukung dari meningkatkan citra Kanwil Kemenag Provinsi Jambi dalam hal pelayanan prima di PTSP adalah bentuk pelayanan yang diberikan kepada masyarakat dan, sarana dan prasarana yang diberikan sangat mendukung dari pelayanan, sedangkan faktor penghambat adalah masih kurangnya SDM yang berkompeten di PTSP, dan masih banyak nya masyarakat yang belum mengetahui sistem administrasi pelayanan yang diberikan terutama sistem administrasi secara daring.
\end{abstract}

Kata-kata kunci: Pelayanan Prima, PTSP, Kementrian Agama, Jambi.

\section{A. Pendahuluan}

Kementerian Agama RI sebagai lembaga pemerintah yang membutuhkan kepercayaan publik harus memiliki citra dan reputasi yang baik. Hal ini dikarenakan sebagian masyarakat melihat bahwa Kementerian Agama sebagai lembaga yang membawa nama agama melakukan tugas dan kewajibannya menggunakan nilai-nilai keagamaan. Hal ini pulalah yang menuntut Kementerian Agama RI memiliki citra yang baik di mata masyarakat. 
Citra sebuah organisasi tidak bisa direkayasa. Artinya citra akan datang dengan sendirinya dari upaya yang ditempuh sehingga komunikasi dan keterbukaan perusahaan merupakan salah satu faktor utama untuk mendapatkan citra perusahaan yang positif. Citra positif yang dibangun dan melekat terhadap lembaga adalah citra yang dibuat melalui tahap-tahap yang panjang dan dikerjakan secara sungguh-sungguh karena yang menilai bukanlah pihak atau lembaga melainkan masyarakat.

Citra sebuah lembaga atau organisasi diartikan sebagai pandangan atau anggapan yang organisasi dapatkan dari pihak lain atau para stakeholdernya. Sebuah citra organisasi mempresentasikan baik atau buruk dari pelanggan, investor, karyawan dan publik umum atau masyarakat. Berdasarkan konsep ini, citra Kementerian Agama sudah dapat dikatakan baik. Ini dibuktikan dengan anggapan para stakeholder Kementerian Agama yang menilai bahwa citra saat ini dapat dikatakan baik. Anggapan atau penilaian positif tentang Kementerian Agama saat ini muncul dari berbagai kalangan, mulai dari pegawai dan pejabat Kementerian Agama sampai dengan jurnalis.

Sebagaimana survei yang dilakukan oleh beberapa lembaga survei itu baik kinerja para pegawai maupun lembaga Kementerian Agama itu dipandang baik oleh masyarakat. Salah satunya hasil survei publik Lembaga Survei Indonesia (LSI) terhadap Kinerja Kabinet Jokowi-JK pada awal 2015, menempatkan Menteri Agama Lukman Hakim Saifuddin sebagai menteri dari Bidang Pembangunan Manusia dan Kebudayaan Masyarakat (PMK) dengan kinerja yang paling memenuhi harapan dengan menduduki inilai $48,4 \%$. Persentasi ini berada pada tingkatan teratas dari delapan menteri yang masuk dalam kategori ini. Disusul oleh Menteri Sosial (48,3\%), Menteri Kebudayaan Pendidikan Dasar dan Menengah (47,5\%), Menteri Kesehatan (43,5\%), Menteri Pemuda dan Olah Raga (37,7\%), Menteri Riset, teknologi, dan Pendidikan Tinggi (36,45\%),Menteri Pemberdayaan Perempuan dan Perlindungan Anak (36,2\%), dan Menteri Desa dan Pembangunan Daerah Tertinggal dan Transmigrasi (33,4\%). Akan tetapi, 
ditingkat kabinet/menteri, mayoritas warga tidak mengetahui kinerja mereka. Hanya kinerja Menteri Kelautan yang dianggap mayoritas publik (61\%) memenuhi harapan. Untuk tiga menteri, Menteri Agama, Menteri Sosial, dan Menteri Diknas, hampir separuh (47-48\%) mengatakan bahwa kinerja mereka memenuhi harapan. Sisanya publik yang menganggap kinerja menteri sesuai harapan jumlahnya di bawah 40\%," demikian disebutkan dalam temuan Survei LSI tersebut. Sehingga dapat dikatakan bahwa penilaian khalayak atau pengetahuan khalayak terhadap kinerja dan lembaga Kementerian Agama cukup baik karena Kementerian Agama memiliki grade atau pelayanan yang cukup positif. ${ }^{1}$

Perkembangan teknologi menjadikan instansi berlomba-lomba untuk memberikan pelayanan terbaik (Excellent service) demi kenyaman masyarakat dengan tujuan meningkatkan citra sebuah instansi. Banyak lembaga maupun instansi pemerintah memperbaiki sistem pelayanan dengan memanfaatkan perkembangan tekhnologi dan hal ini segera ditindak lanjuti oleh pemerintah dalam meningkatkan citra dan yang ingin memberikan pelayan prima kepada masyarakat dengan mulai memperbaiki sistem pelayanan yang ada.

Layanan dalam sudut pandang Islam sendiri di pandang sebagai suatu hal yang sangat di perhatikan hal tersebut selaras dengan firman Allah dalam surah Al-Maidah ayat:2

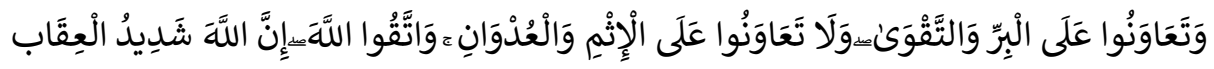
(الماعدة:r)

"Dan tolong-menolonglah kamu dalam (mengerjakan) kebajikan dan takwa, dan jangan tolong menolong dalam berbuat dosa dan pelanggaran. Dan bertakwalah kamu kepada Allah, sesungguhnya Allah amat berat siksanya."(Qs. Al-Maidah:2)2

${ }^{1}$ LSI: kinerja Menag Lukman Hakim Saifuddin Memenuhi Harapan, di akses melalui web, http://www.antara.com, pada tanggal 12-02-2020

${ }^{2}$ Alquran, Almaidah:2, Al-Ally Alquran dan Terjemahnya, (Jawa Barat: CV Diponegoro:2005 ), 93 
Citra dapat timbul melalui akan adanya pemahaman dalam diri individu, tentunya pemahaman tersebut terbentuk dari kenyataan yang dirasakan oleh masyarakat dalam pelayanan yang diberikan oleh PTSP. Pemerintah Daerah sebagai pemberi kewenangan harus bertanggung jawab atas konsekuensi pemberian hak dan kewajiban dalam mencapai tujuan seperti peningkatan pelayanan terhadap kebutuhan masyarakat diupayakan dengan sebaik-baiknya. Untuk melaksanakan pelayanan publik yang lebih optimal, maka Pemerintah Daerah wajib melakukan pembenahan dalam mempersiapkan diri dari berbagai kekurangan-kekurangan pada tiap daerah masing-masing. Salah satunya dengan melakukan pembenahan pada sistem pelayanan yang belum menunjukan adanya efisiensi dan efektivitas bagi pemerintah dan masyarakat di tiap tahunnya.

Salah satu bentuk yang ditawarkan sebuah instansi pemerintah adalah dengan menyediakan jasa yang memberikan layanan sesuai dengan gaya hidup pengguna masa kini agar instansi pemerintah mendapatkan citra positif dari masyarakat, dengan tujuan masyarakat dapat merasakan kenyamanan dalam melakukan proses pelayanan pada suatu dinas/instansi terkait. Artinya pada kondisi maupun situasi saat ini setiap pemerintahan pusat maupun daerah harus dapat mewujudkan pelayanan publik yang berkualitas. ${ }^{3}$

Pada penyelenggaraan Pelayanan Publik sekurang-kurangnya meliputi pelaksanaan pelayanan, pengelolaan pengaduan masyarakat, pengelolaan informasi, pengawasan internal penyuluhan kepada masyarakat dan pelayanan konsultasi. Ini merupakan salah satu bentuk komitmen pemerintahan dalam meningkatkan pelayanan adalah dengan pelaksanaan kebijakan Pelayanan Terpadu sebagai proses pelayananpublik yang berkualitas sebagai cara pemerintah dalam membenahi kualitas pelayanan yang ada dinas/instansi terkait.

Pemerintah pun telah memberikan kepastian hukum tentang penyelenggaraan pelayanan publik, ketentuan tersebut tertuang dalam UU

${ }^{3}$ Hardiyansyah, Komunikasi Pelayanan Publik (Yogyakarta:Gava Media,2015), 3 
Republik Indonesia No. 25 Tahun 2009 Tentang Pelayanan Publik. Undangundang tersebut telah menjelaskan secara rinci tentang penyelenggaraan pelayanan publik. Pelayanan publik merupakan "Pemberian layanan (melayani) keperluan orang atau masyarakat yang mempunyai kepentingan pada organisasi itu sesuai dengan aturan pokok dan tata cara yang telah ditetapkan." 4

Peningkatan kualitas pelayanan perlu dilakukan oleh instansi pemerintahan yaitu dalam bentuk pelayanan prima agar dapat memberikan pelayanan yang terbaik, inovasi-inovasi dalam pelayanan publik mutlak diperlukan agar pelayanan publik semakin murah, cepat, dan baik.

Langkah pemerintah dalam meningkatkan kualitas pelayanan prima bagi masyarakat adalah dengan mengimplementasikan pelayanan terpadu satu pintu (PTSP). Dasar hukum dari pelayanan terpadu satu pintu tertuang dalam Peraturan Menteri Dalam Negeri No. 24 Tahun 2006 tentang Pedoman Penyelenggaraan Pelayanan Perijinan Terpadu Satu Pintu.Tujuan dari dibentuknya pelayanan terpadu satu pintu yaitu:

[U]ntuk meningkatkan kualitas layanan publik dan memberikan akses yang lebih luas kepada masyarakat untuk memperoleh pelayanan public". ${ }^{5}$

Dengan adanya layanan ini bisa memangkas birokrasi yang ada, dan dapat memberikan pelayanan yang prima kepada masyarakat. Pelayanan prima menjadi pelayanan terbaik yang diberikan oleh penyedia layanan kepada pelanggan, bertujuan untuk meningkatkan citra sebuah instansi. Pelayanan prima memiliki ciri khas dalam hal kualitas, seperti kemudahan, kecepatan, ketetapan, kehandalan, dan empati dari petugas penyedia. Dengan adanya pelayanan prima yang baik dari petugas penyedia layanan maka masyarakat tak akan lagi mengeluhkan atas lamanya pelayanan. Masyarakat akan merasakan kenyamanan dalam proses pelayanan di suatu instansi. Pelayanan prima bukan

\footnotetext{
${ }^{4}$ Lihat Lijan Poltak Sinambela, Reformasi Pelayanan Publik: Teori, Kebijakan, dan Implementasi, (Jakarta: PT Bumi Aksara, 2010 ), 5

${ }^{5}$ Lihat Anonim, Peraturan Menteri Dalam Negeri No. 24 Tahun 2006 tentang PedomanPenyelenggaraan Pelayanan Perijinan Terpadu Satu Pintu, 3.
} 
hanya terfokus pada masalah nonfisik saja, namun dari segi fisik juga sangat diperhatikan. Pihak penyedia layanan seyogyanya memberikan fasilitas fisik berupa ruangan yang nyaman,

Dalam meningkatkan citra, pelaksanaan pelayan prima juga menuntut SDM yang bagus, menguasai teknologi dan informatika dan memiliki etika yang baik dalam berkomunikasi kepada masyarakat atau pubik. Dengan kualitas SDM yang bagus maka akan berdapak kepada instansi terkait karna jika petugas itu memberikan layanan terbaik maka masyarakat akan mengingat itu baik, dan sebaliknya jika layanan itu buruk maka masyarakat akan meberikan penilaian buruk. Para petugas juga di minta untuk mempunyai kesabaran yang tinggi dan selalu memberikan senyum karna dalam melayani masyarakat petugas akan bertemu dengan berbagai macam karakter.

Pelayanan Terpadu Satu Pintu (PTSP) di Kanwil Kemenag Jambi di launching pada Oktober 2018 yang diresmikan langsung oleh Menteri Agama Lukman Hakim Saifuddin. Jambi sendiri merupakan provinsi ke-17 yang telah memiliki PTSP, dan akhir tahun ini semua harus sudah memiliki PTSP, ujarnya. ${ }^{6}$ Dengan adanya nya PTSP di Kanwil Kemenag Jambi ini diharapkan para petugas lebih mendekatkan diri kepada masyarakat dan sekaligus membangun kepercayaan karena PTSP yang berbasis online maka tranparansi terwujud, semakin mempercepat dan memperudah dalam pengurusan informasi dan perizinan. Menag mengapresiasi PTSP di Kanwil Kemenag Jambi karena memiliki layanan terbanyak se-Indonesia, ujarnya". ${ }^{7}$

Pelayanan publik yang di berikan instansi pemerintah belum dapat di katakan prima dan memenuhi standar operasional pelayanan (SOP) sehingga citra yang terbentuk pun belum baik di mata masyarakat. Dikarenakan banyaknya keluhan masyarakat tentang pelayanan yang mereka dapatkan. Seperti keluhan tidak adanya kepastian waktu sehingga mengakibatkan

${ }^{6}$ Di akses melalui web, http://Jambi.kemenag.go.id, tanggal, 20-01-2020

${ }^{7}$ Ibid, 
rendahnya pelayanan. Ketidakpastian ini menyebabakan citra yang kurang baik terhadap instansi pemerintah tersebut. Berdasarkan temuan observasi tersebut menyatakan bahwa Implementasi pelayanan publik baik oleh pemerintah pusat maupun daerah masih memprihatinkan dapat dilihat dari data Ombudsman Republik Indonesia yang menyatakan bahwa

Rata-rata implementasi tersebut berada di bawah 30 persen. Tingkat kementerian 22,2 persen, lembaga negara dan pemerintahan 27 persen dan pemerintah daerah 10,5 persen. Semakin rendah implementasi pelayanan publik, dapat memicu meningkatnya potensi pungutan liar (pungli dan korupsi) serta dapat dinilai bahwa Instansi pelayanan publik telah mengabaikan Undangundang Pelayanan Publik dan membiarkan atau menumbuhkan potensi terjadinya pungli dan korupsi di sektor pelayanan publik. ${ }^{8}$

Rendahnya kepatuhan Organisasi Perangkat Daerah (OPD) terhadap implementasi Standar Pelayanan Publik adalah kendala utama kualitas pelayanan di seluruh instansi pemerintah kita. Rendahnya kepatuhan/implementasi Standar Pelayanan mengakibatkan berbagai jenis maladministrasi berikutnya yang didominasi oleh perilaku aparatur negara. Misalnya, ketidakjelasan prosedur, ketidakpastian jangka waktu layanan, pungutan liar, korupsi, ketidakpastian layanan perijinan investasi, kesewenang-wenangan dan secara makro mengakibatkan rendahnya kualitas pelayanan publik. ${ }^{9}$

Selain itu untuk meningkatkaan citra dalam hal pelayanan prima dibutuhkan fasilitas sarana maupun prasarana yang menunjang agar PTSP yang diterapkan bisa lebik baik. Hal tersebut juga tidak terlepas pada tugas dan tanggung jawab bagi kinerja sumber daya manusia pada Kanwil Kemenag Provinsi Jambi agar bisa menjalankan program-programnya dan dapat

\footnotetext{
${ }^{8}$ Lihat"Laporan pengaduan pelayanan publik ke Ombudsman" diakses melalui web http:/www.ombudsman.go.id//peristiwa-laporan-pengaduan-pelayanan-publik-ke-ombudsmanmeningkat-350 tanggal 28 Januari 2020

${ }^{9}$ Lihat "Pelayanan Publik dan kepuasan masyarakat, di akses melalui web https://www.ombudsman.go.id/artikel/r/artikel--layanan-publik-dan-kepuasan-masyarakat, tanggal 28-Januari-2020
} 
menjalankan pelayanan dengan baik bagi masyarakatnya misalnya dengan pemanfaatan teknologi dan kualitas pelayanan yang diberikan, maka masyarakat tidak perlu datang ke instansi tapi cukup menggunakan fasilitas yang tersedia seperti Mora-smartOffice yang mana masyarakat bisa langsung mengupload yang disediakan oleh PTSP Kanwil Kemenag Provinsi Jambi yang yang bisa langsung di akses oleh masyarakat melalui web www.jambi.ptsp.web.id. Mora Smart-Office yang dimiliki oleh Kanwil Kemenag Provinsi Jambi menjadi salah satu dari 9 Inovasi layanan terbaik di Kemeng tahun 2020. Seperti yang di kutip dari web Kementerian Agama RI sebagai berikut:

[S]elain inovasi MAN 2 Kulon Progo, Kementerian Agama juga mengirimkan 12 program inovasi dari sembilan satuan kerja. Kami sangat mengapresiasi semua Satker di Kementerian Agama, terutama MAN 2 Kulon Progo yang berhasil masuk pada Top 99 KIPP dan 12 peserta lainnya. Itu adalah inovasiinovasi terbaik yang dilakukan satuan kerja Kemenag," ${ }^{10}$ Jelas Plt Sekjen Nizar, Rabu (08/07).

Nizar juga menambahkan,

[K]ita berharap ke depan lebih banyak inovasi yang muncul dari satuan-satuan kerja Kemenag. Apalagi saat ini kita tengah menghadapi pandemi. Mari mulai melakukan inovasi dan kreasi dengan thinking out of the box untuk bisa memberikan layanan publik yang lebih optimal, nyaman, dan aman bagi masyarakat. ${ }^{11}$

Adapun 9 satuan kerja dengan 12 Inovasi Layanan Publik Terbaik di Kemenag tahun 2020, sebagai berikut:

1. Kanwil Kementerian Agama Daerah Istimewa Yogyakarta dengan program inovasi:

- Si KETAN ARGA (Sistem Ketahanan Keluarga) di KUA Nanggulan: Dari Nanggulan untuk Indonesia, dan

- MAN de MOTEFA: Menciptakan Madrasah Technopreneur pada MAN 2 Kulon Progo,

2. Kanwil Kemenag Jambi dengan program inovasi:

${ }^{10}$ Nizar, Plt Sekjen, di akses melalui website http://kemenag.go.id, tanggal 23-Juli-2020

${ }^{11}$ Ibid 
- MORA Smart Office, dan

- WFH Online Report,

3. Kanwil Kemenag Lampung dengan program inovasi Zakat Profesi Kanwil, Kankemenag Kabupaten Kapuas Kalimantan Tengah dengan program inovasi Teman PNBP NR (Sistem Penyetoran Penerimaan Negara Bukan Pajak dari Nikah Rujuk),

4. Kankemenag Kota Denpasar dengan program inovasi RUMAH BINAR,

5. IAIN Salatiga dengan program inovasi KUMIS AKI,

6. IAIN Pare-pare dengan program inovasi Literasi Digital Pengembangan Teknopreneur Pengolahan Kopi Desa Latimojong,

7. UIN Malang Jatim dengan program inovasi:

8. Si Performa (Sistem Pelaporan, Informasi dan Realisasi Anggaran), dan Koin Mami Kelor UIN Malang untuk Imunitas Masa Pandemi, serta

9. Direktorat Jenderal Pendidikan Islam dengan program inovasi Indexing MORAREF. ${ }^{12}$

PTSP hadir sebagai pemenuhan kebutuhan pelayanan dengan sistem modern dan praktis. Terlihat dengan berbagai macam pelayanan yang diberikan PTSP, khususnya PTSP milik Kemenag Provinsi Jambi telah memberikan pelayanan dengan sistem online yang bernama Mora-Smart Office, yang diharapkan mampu memberikan pelayanan yang prima kepada costumer. Namun masih banyak masyarakat yang belum mengetahui tentang pelayanan online ini. Karena masih banyak masyarakat yang datang langsung ke PTSP Kanwil Kemenag.

Berdasarkan latar belakang tersebut maka penelitian ini bertujuan mengetahui pengaruh pelayanan prima yang di berikan oleh PTSP terhadap Citra Kanwil Kemenag.

\footnotetext{
${ }^{12}$ Nizar, Plt Sekjen, di akses melalui website http://kemenag.go.id, tanggal 23-Juli-2020
} 


\section{B. Pengaruh Pelayanan PTSP di Kementrian Agama Jambi}

Menurut Kamus Besar Bahasa Indonesia edisi kedua, kata pengaruh yakni "daya yang ada atau timbul dari sesuatu (orang atau benda) yang ikut membentuk watak kepercayaan dan perbuatan seseorang". Pengaruh adalah "daya yang ada atau timbul dari sesuatu (orang atau benda) yang ikut membentuk watak kepercayaan dan perbuatan seseorang.

WJS.Poerwardaminta berpendapat bahwa pengaruh adalah daya yang ada atau timbul dari sesuatu, baik orang maupun benda dan sebagainya yang berkuasa atau yang berkekuatan dan berpengaruh terhadap orang lain. Bila ditinjau dari pengertian diatas, maka dapat disimpulkan bahwa pengaruh adalah sebagai suatu daya yang ada atau timbul dari suatu hal yang memiliki akibat atau hasil dan dampak yang ada. ${ }^{13}$

Pelayanan prima merupakan terjemahan dari istilah Excellent Service yang secara harfiah berarti pelayanan yang terbaik atau sangat baik. Disebut sangat baik atau terbaik karena sesuai dengan standar pelayanan yang berlaku atau dimiliki instansi pemberi layanan. Hakekat pelayanan pulik adalah pemberian pelayanan prima kepada masyarakat yang merupakan perwujudan kewajian aparatur pemerintah sebagai abdi masyarakat. ${ }^{14}$

[M]enurut Fandy Tjiptono, untuk mengukur tingkat keberhasilan pelayanan prima perlu memperhatikan beberapa faktor diantaranya adalah mengukur determinan utama kualitas jasa, mengelola ekspektasi pelanggan, mengelola bukti kualitas jasa, mendidik konsumen tentang jasa, menumbuh kembangkan budaya kualitas, menciptakan automating quality, menindak lanjuti jasa, mengembangkan sistem informasi kualitas jasa. ${ }^{15}$ Penelitian ini hanya memakai empat indikator yaitu, pertama mengukur determinan utama kualitas jasa, mengelola ekspektasi pelanggan, mengelola bukti kualitas jasa, menumbuh kembangkan budaya kualitas. ${ }^{16}$

\footnotetext{
${ }^{13}$ Pengertian pengaruh, di akses melalui web http://digilib.unila.ac.id, tanggal 3-Juli-2020

${ }^{14}$ Daryanto dan Ismanto, Konsumen Dan Pelayanan Prima, (Yogyakarta, Gava Media: 2014), 107

${ }^{15}$ Fandy Tjiptono, Service Management Mewujudkan Layanan Prima, (Yogyakarta, CV. Andi Offsett :2008), 99.

${ }^{16}$ Ibid., hlm.108.
} 
[P]elayanan prima menurut A.K.P Adya Brata mengartikan pelyanan prima dengan menggunakan rumus SERVICE yaitu, Self awareness (menanamkan kesadaran diri, menanamkan pelayanan dengan benar), Enthusiasm (pelayanan dengan penuh gairah), Reform (memperbaiki kinerja pelayanan), Value (pelayanan dengan nilai tambah), Impressive (penampilan menarik), Care (perhatian,) Evaluation (mengevaluasi layanan. ${ }^{17}$

Jadi, Pelayanan Prima (Excellence Service) adalah sistem yang menyediakan sesuatu yang dibutuhkan oleh publik yang memenuhi kebutuhan praktis dan emosional publik dengan memperhatikan indikator determinan utama kualitas jasa, mengelola ekspektasi pelanggan, mengelola bukti kualitas jasa, dan menumbuh kembangkan budaya kualitas sehingga pelayanan yang diberikan berkesan kuat dan dapat dirasakan langsung oleh publik.

\section{PTSP (Pelayanan Terpadu Satu Pintu)}

Pelayanan Terpadu Satu Pintu (PTSP) adalah penyelenggaraan suatu kegiatan Perizinan dan Non perizinan yang mendapatkan pelimpahan wewenang dari lembaga/instansi yang memiliki kewenangan perizinan dan nonperizinan dimana proses pengelolaannya mulai dari tahap permohonan sampai tahap terbitnya dokumen yang di lakukan dalam satu tepat. PTSP di Kemenag ini perizinan yang ada di Kemenag dalam satu tempat, tanpa masyarakat/pemohon perizinan pergi ketempat lain sehingga dapat memenerikan pelayanan yang transparan, dengan perlakuakan yang sama, mudah, efisien, cepat, adil, akuntabilitas dan kepastian hukum. Pendirian PTSP ini berdasarkan atas Peraturan Presiden RI No 97 Tahun 2014 tentang Penyelenggaraan Pelayanan Terpadu Satu Pintu. ${ }^{18}$ Pada tanggal 21 Oktober 2015 yakni satu tahun pemerintahan Joko Widodo dan Jusuf Kalla mampu memperbaiki kinerja 2010), 15

${ }^{17}$ Nina Rahmayanty, Manajemen Pelayanan Prima, Cet.I, (Yogyakarta, Graha Ilmu:

${ }^{18}$ Di akses melalui weeb, https://pusdiklat.bkpm.go.id, pada tanggal 14 Mei 2018. 
pelayanan publik melalui sistem PTSP di beberapa sektor, ${ }^{19}$ temasuk kinerja di dalam Kemenag. Maka sudah sangat jelas PTSP adalah program yang sudah lama. Penelitian ini menggunakan penelitian kualitatif Pendekatan penelitian menggunakan pendekatan deskriptif. Penelitian deskriptif adalah penelitian yang berusaha mendeskripsikan suatu gejala peristiwa, keajdian yang terjadi saat sekarang.

Data primer adalah data yang diperolehh langsung dari sumber pertama (first hand) melalui observasi atau wawancara di lapangan. Dalam hal ini data yang diinginkan adalah tentang Pengaruh Pelayanan Prima di Pelayanan Terpadu Satu Pintu (PTSP) Terhadap Citra Kantor Wilayah Kementerian Agama Provinsi Jambi. Sementara data sekunder adalah data yang diperoleh dari sumber kedua berupa dokumentasi serta peristiwa yang bersifat lisan dan tertulis.

\section{Profil Kantor Wilayah Kementerian Agama Provinsi Jambi}

Cikal bakal berdirinya Kementerian Agama bermula dari usul utusan Komite Nasional Indonesia (KNI) Daerah Keresidenan Banyumas pada Rapat/ Sidang Pleno Komite Nasional Indonesia Pusat KNIP (sekarang DPR/ MPR RI) tanggal 24 28 November 1945 di Gedung Fakultas Kedokteran Salemba Jakarta. Usul yang disampaikan oleh KH. Abu Dardiri, KH. Soleh Suady dan M.Soekoso Wirjosapoetro bahwa hendaknya urusan agama diurusi oleh kementrian khusus dan tersendiri. Atas apresiasi Muhammad Natsir, Dr. Moewardi, Dr. Marzoeki Mahdi, Kartosoedarmo dan anggota KNIP yang lain mendukung dan memperkuat usul tersebut. Usul tersebut disampaikan kepada Perdana Menteri Sutan Syahrir, kemudian diteruskan kepada Presiden untuk mendapat persetujuan.

Moh. Hatta yang saat itu menjabat Wakil Presiden menjanjikan bahwa usul tersebut akan mendapat perhatian sungguh-sungguh dari pemerintah. Diperkirakan 1 bulan setelah usul itu, yakni 3 Januari 1946 (29 Muharram 1364

${ }^{19}$ Di akses melalui web, www.kemenag.co.id, pada tanggal 14 Mei 2018. 
H) keluarlah Penetapan Presiden RI No. 1/SD/1946 yang berbunyi Presiden Republik Indonesia, mengingat usul Perdana Menteri dan Badan Pekerja Komite Nasional Indonesia Pusat, memutuskan untuk mengadakan Kementerian Agama.

Berita berdirinya Kementrian Agama tersebar di kalangan masyarakat melalui siaran Radio Republik Indonesia (RRI), Koran-koran perjuangan dan dari mulut ke mulut. Pada tanggal 2 September 1945 (pada masa kabinet RI/ Kabinet Presidentil Presiden Soekarno), sebenarnya telah terbentuk 14 kementrian dan 4 Menteri Negara; tetapi pemerintah tidak sekaligus memberntuk Kementrian Agama. Hal itu antara lain karena; Tengah menetapkan politik, ekonomi, pendidikan, sarana, sosial, pertahanan/ keamanan, dll. Segera setelah kemerdekaan Indonesia, para pemimpin negara disibukkan oleh perebutan kekuasaan (dari tangan Jepang) yang memerlukan waktu dan perjuangan fisik;

Pembentukan kementerian sering tertunda pada setiap sidang pleno KNIP karena masalah situasi dan mendesaknya keamanan rakyat. Kementerian Agama benar-benar terbentuk pada masa kabinet Syahrir/ Kabinet Parlementer I dengan HM. Rasyidi sebagai Menteri Agama, yang sebelumnya sebagai Menteri Negara; sedangkan Sekretaris Jenderal Kementerian Agama dijabat MR. A. Soebagyo. Pada tanggal 4 Januari 1946 (hari kedua pendirian Kementerian Agama) Pusat Pemerintahan Negara RI pindah ke Yogyakarta sebagai kantor sementara sebelum akhirnnya pusat pemerintahan Negara RI kembali ke Jakarta.

\section{Pengaruh Pelayanan Prima Humas PTSP terhadap Citra Kanwil Kemenag Provinsi Jambi}

Sebagai salah satu fasilitas layanan public milik Kanwil Kemenag Provinsi Jambi, pelayanan terpadu satu pintu (PTSP) selalu berupaya untuk meningkatkan perfoma pelayanan serta melakukan inovasi dalam rangka perbaikan dan optimalisasi layanan pada pelayanan terpadu satu pintu (PTSP) dengan tujuan meningkatkan citra Kanwil Kemenag. Hadir sebagai penjawab keresahan masyarakt dalam berbirokrasi PTSP sebagai titik pandang pertama pada Kanwil 
Kemenag Provinsi Jambi dalam hal pelayanan berupaya memberikan pelayanan yang prima. Seperti yang penulis kutip dari website Kanwil Kemenag provinsi Jambi, Menag Lukman Hakin Saifuddin dalam rangka peresmian PTSP di Kanwil Kemenag provinsi Jambi sebagai berikut:

[I]ni merupakan wujud komitmen, tekad kita untuk bagaimana agar kita semakin mendekatkan diri kepada masyarakat dalam memberikan pelayanan khususnya terkait dengan hal ihwal kehidupan keagamaan, juga sekaligus membangun trust kepada PTSP yang berbasisi sistem aplikasi online maka transparansi terwujud, semakin mempercepat, mempermudah dan menjadi murah segala pengurusan terkait permintaaan informasi dan perizinan. ${ }^{20}$

Pelayanan prima adalah kunci keberhasilan sebuah institusi atau pun perusahaan dalam bentuk memberikan pelayanan terbaik. Dengan begitu masyarakat yang diberikan pelayann prima akan merasa puas dengan pelayanan yang diberikan. Bentuk pelayanan prima di antaranya ramah, senyum, sopan, cepat, tepat, terbuka, dan tanggung jawab yang memberikan pelayanan terbaik sesuai dengan standar pelayanan yang berlaku atau dimiliki instansi pemberi pelayanan. Hakekat pelayanan publik adalah pemberian pelayanan prima kepada masyarakat yang merupakan perwujudan kewajiban aparatur pemerintah sebagai abdi masyarakat.

Pemerintah pun memastikan para pegawai memberikan pelayan dengan setulus hati kepada masyarakat yang ingin mengurus berbagai macam administrasi di Kanwil Kemenag Provinsi Jambi. Seperti pernyataan hasil wawancara peneliti kepada pegawai bagian PTSP Kanwil Kemenag Provinsi Jambi ibu Kurnia Ulfa.

[P]TSP dibentuk dengan semangat untuk memberikan pelayanan prima yang lebih efefktif, efisien, ekonomis dan akuntabel. PTSP Kanwil Kemeneterian Agama Provinsi Jambi memiliki prinsip pelayanan SMART, yaitu: Senyum, Mudah, Amanah, Ramah dan Trasnparan. Kami selalu berusaha memberikan pelayanan yang membuat masyarakat nyaman dan merasa sebagai seorang raja yang di layanai sepenuh hati, dan pelayanan

${ }^{20}$ Menag Lukman Hakim Saifuddin, dalam rangka peresmian PTSP Kanwil Kemenag Provinsi Jambi, di akses melalui website https://jambi.kemenag.go.id, tanggal 20-Maret-2020 
prima ini kami berikan kepada masyarakat eksternal maupun internal seperti para pegawai kanwil yang ingin berurusan bisa langsung pergi ke PTSP. ${ }^{21}$

Berdasarkan dari wawancara diatas untuk melakukan pelayanan prima Kanwil Kemenag Jambi berusahaha selalau memberikan pelayanan yang terbaik, mudah, untuk dimengerti oleh masyarakat yang hendak berurusan dengan Kanwil Kemenag Jambi. Selain itu pelayanan di PTSP selalu siap untuk melayani masyarakat selama jam kerja berlangsung yang bertujuan untuk memberikan pelayanan yang terbaik kepada masyarakat.

Pelayanan prima adalah kunci keberhasilan sebuah institusi atau pun perusahaan dalam bentuk memberikan pelayanan terbaik. Dengan begitu masyarakat yang diberikan pelayann prima akan merasa puas dengan pelayanan yang diberikan. Bentuk pelayanan prima di antaranya ramah, senyum, sopan, cepat, tepat, terbuka, dan tanggung jawab yang memberikan pelayanan terbaik sesuai dengan standar pelayanan yang berlaku atau dimiliki instansi pemberi pelayanan. Hakekat pelayanan publik adalah pemberian pelayanan prima kepada masyarakat yang merupakan perwujudan kewajiban aparatur pemerintah sebagai abdi masyarakat.

\section{E. Penutup}

Berdasarkan pembahasan diatas maka dapat ditarik kesimpulan bahwa Citra menjadi harga mati oleh setiap instansi baik pemerintah maupun swasta. PTSP Kanwil Kemenag Provinsi Jambi Baru diresmikan, pemerintah berharap PTSP ini memangkas birokrasi, dan PTSP ini memberikan dampak yang positif terhadap citra Kanwil Kemenag Provinsi Jambi. Pengaruh pelayanan prima di PTSP terhadap citra Kanwil Kemenag Provinsi Jambi yaitu memberikan pelayanan yang ramah, cepat dan mudah; memberikan rasa puas terhadap customer; Maret 2020

${ }^{21}$ Kurnia Ulfa, pegawai PTSP Kanwil Kemenag provinsi Jambi, Wawancara pada 16 
bertanggung jawab; mekanisme dan pelayanan prosedur; biaya administrasi pelayanan; petugas mampu berkomunikasi dengan baik. Faktor-faktor yang mempengaruhi pelayanan prima pada PTSP Kanwil Kemenag Provinsi Jambi terdapat dua faktor, yaitu faktor pendukung dan penghambat. Faktor pendukungnya adalah sumber daya manusia di PTSP merupakan SDM yang memiliki kepribadian yang sabar, sopan, baik dan telah diberikan training sebelumnya. Kemudian sarana dan prasarana yang diberikan di PTSP sangat memadai untuk menunjang proses pelayanan serta memberikan kenyamanan pada customer. Sedangkan faktor penghambat adalah SDM yang belum berkompetensi dibidangnya dan masih banyak masyarakat yang belum mengerti akan prosedur pelayanan yang diberikan oleh Kanwil Kemenag Provinsi Jambi dan masyarakat masih banyak menggunakan sistem manual atau datang ke PTSP secara langsung, dibandingkan mengupload berkas adminitrasi ke wesbsite yang telah disediakan oleh pihak PTSP. 


\section{Daftar Pustaka}

Alquran, Al-Ally Alquran dan Terjemahnya, (Jawa Barat: Diponegoro:2005)

Asep, Syamsul dan M. Romli, Jurnalistik Praktis: Untuk pemula, (Bandung: Remaja Rosdakarya, 2009)

Buku Pintar Pelayanan Terpadu Satu Pintu Kantor Wilayah Kementerian Agama Provinsi Jambi, (Raker: 2018)

Daryanto dan Ismanto, Konsumen Dan Pelayanan Prima, (Yogyakarta, Gava Media: 2014)

Harbani Pasalong, Teori Administrasi Publik, (Bandung, Alfabeta: 2008)

Kanwil Kemenag Provinsi Jambi, Renacana Strategis (RENSTRA, 2018)

Indrawan, Rully dan Poppy Yaniawati, Metodologi Penelitian Kuantitatif,

Kualitatif, dan Campuran untuk Manajemen, Pembangunan, dan Pendidikan (Bandung: Refika Aditama 2016)

lexy, Moeleong j, Metodologi Penelitian Kualitatif, ( Bandung: Remaja Rosdakarya Offset 1996)

Moenir, H.A.S, Manajemen Pelayanan Umum di Indonesia, (Jakarta, Bumi Akasara:2008)

Pusat Bahasa Depatermen Pendidikan Nasional, Kamus Besar Bahasa Indonesia (KBBI), (Jakarta: Pusat Bahasa, 2008)

Rahayu, lin Tri\& Tristiadi Ardi Ardani, Observasi \& Wawancara, (Jatim : Bayumedia Publishing, 2004)

Rahmayanty, Nina. Manajemen Pelayanan Prima, Cet.I, (Yogyakarta: Graha IImu, 2010)

Ratminto \& Atik Septi W. Manajemen Pelayanan (Pengembangan Model Konseptual, Penerapan Citizen's Charter dan Standar Pelayanan Minimal), (Yogyakarta: Pustaka Pelajar, 2005)

Santosa, Pandji, Administrasi Publik Teori dan Aplikasi Good Governance, (Bandung: Radika Utama, 2008) 
Sinabela, Lijan Poltak, Reformasi Pelayanan Publik: Teori, Kebijakan, dan Implementasi, (Jakarta: Bumi Aksara, 2010 )

Sugiono, Metode Penelitian Kuantitatif, dan R\&D (Bandung: Alfabeta, 2010)

Tjipno, Fandy, Service Management Mewujudkan Layanan Prima, (Yogyakarta: Andi Offset, 2008)

Wahab, Solichin Abdul, Analisis Kebijakan dari Formulasi ke Implementasi Kebijakan Negara, (Jakarta: Bumi Aksara, 2008)

Anonim, Peraturan Menteri Dalam Negeri No. 24 Tahun 2006 tentang Pedoman Penyelenggaraan Pelayanan Perijinan Terpadu Satu Pintu, hal.3.

Yusni, Muhammad Ali, "Studi Tentang Pelayanan Haji di Kementerian Agama Kota Samarinda" e-Journal Ilmu Pemerintahan Vol.3.1., 2015

Arif Pujiyanto, "Peranan Public Relations Dalam Memberikan Pelayanan Prima di PT Telkom Kandatel Solo" di akses melalui alamat http://digilib.uns.ac.id, tanggal 26-01-2020

Laporan pengaduan pelayanan publik ke Ombudsman, diakses melalui web http://www.ombudsman.go.id//peristiwa-laporan-pengaduan-pelayanan-publik-keombudsman-meningkat-350 tanggal 28 Januari 2020

Keputusan Menteri Pendayagunaan Aparatur Negara No.63/KEP/M.PAN/7/2003, Tentang Pedoman Penyelenggaraan Pelayanan Publik, di akses melalui web http://asiamaya.com/undang-undang/index kepres.htm

Peraturan Pemerintah RI NOMOR 65 TAHUN 2005 Tentang Pedoman Penyusunan Dan Penerapan Standar Pelayanan Minimal 